\title{
Magnetic Resonance Imaging Signal Changes Mimicking Bone Metastasis in Patients Receiving Bisphosphonate Therapy
}

\author{
Bifosfonat Tedavisi Almış Hastalarda Kemik Metastazını Taklit Eden Manyetik Rezonans \\ Görüntüleme Sinyal Değişiklikleri
}

\section{(1) Ipek Tamsel1, (1) Mehmet Argın', (1) Ayşegül Akgün²}

I Ege University Faculty of Medicine Hospital, Department of Radiology, Izmir, Turkey

2Ege University Faculty of Medicine Hospital, Department of Nuclear Medicine, Izmir, Turkey

\begin{abstract}
Bisphosphonates are inorganic pyrophosphate agents that reduce bone turnover. These agents reduce bone pain and delay skeletal complications, such as fractures in patients with metastatic lytic lesions, malignant-related hypercalcemia, multiple myeloma, Paget's disease of bone, and osteoporosis. Osteonecrosis, developing in the jaw bones specifically, has been described as a complication associated with the use of bisphosphonates. In this report, we presented osteonecrosis-like magnetic resonance imaging findings that can be confused with bone metastasis in two patients who underwent long-term bisphosphonate treatment and the value of bone scan and ${ }^{18}$ flor-fluorodeoxyglucose positron emission tomography/computerized tomography in the differential diagnosis.
\end{abstract}

Keywords: Bisphosphonate, osteonecrosis, long bone, magnetic resonance imaging, bone scan, ${ }^{18} \mathrm{~F}-$ flourodeoxyglucose positron emission tomography/computerized tomography

\section{Öz}

Bisfosfonatlar, kemik döngüsünü azaltan inorganik pirofosfat maddelerdir. Bu ajanlar, metastatik litik lezyonları, malign ilişkili hiperkalsemi, multipl miyelom, kemik Paget hastalı̆ı ve osteoporozu olan hastalarda kemik ağrısını azaltmak ve kırık gibi iskelet komplikasyonlarını geciktirmek için kullanılır. Özellikle çene kemiklerinde gelişen osteonekroz, bisfosfonatların kullanımı ile ilişkili bir komplikasyon olarak tanımlanmıştır. Bu bildiride, uzun dönem bifosfonat tedavisi almış iki olguda kemik metastazını taklit eden osteonekroza ait olabilecek manyetik rezonans görüntüleme bulguları ile birlikte kemik sintigrafisi ve ${ }^{18 f l o r-f l o r o d e o k s i g l u k o z ~ p o z i t r o n ~ e m i s y o n ~ t o m o g r a f i / b i l g i s a y a r l ı ~ t o m o g r a f i n i n ~ t a n ı y a ~ k a t k ı s ı ~ s u n u l m u s ̧ t u r . ~}$ Anahtar kelimeler: Bisfosfonat, osteonekroz, uzun kemik, manyetik rezonans görüntüleme, kemik sintigrafisi, ${ }^{18} \mathrm{~F}$-florodeoksiglikoz pozitron emisyon tomografi/bilgisayarlı tomografi

Address for Correspondence: İpek Tamsel MD, Ege University Faculty of Medicine Hospital, Department of Radiology, İzmir, Turkey Phone: +90 5332341124 E-mail: ipektamsel@yahoo.com ORCID ID: orcid.org/0000-0003-3629-2386 Received: 15.03.2020 Accepted: 31.05.2020 

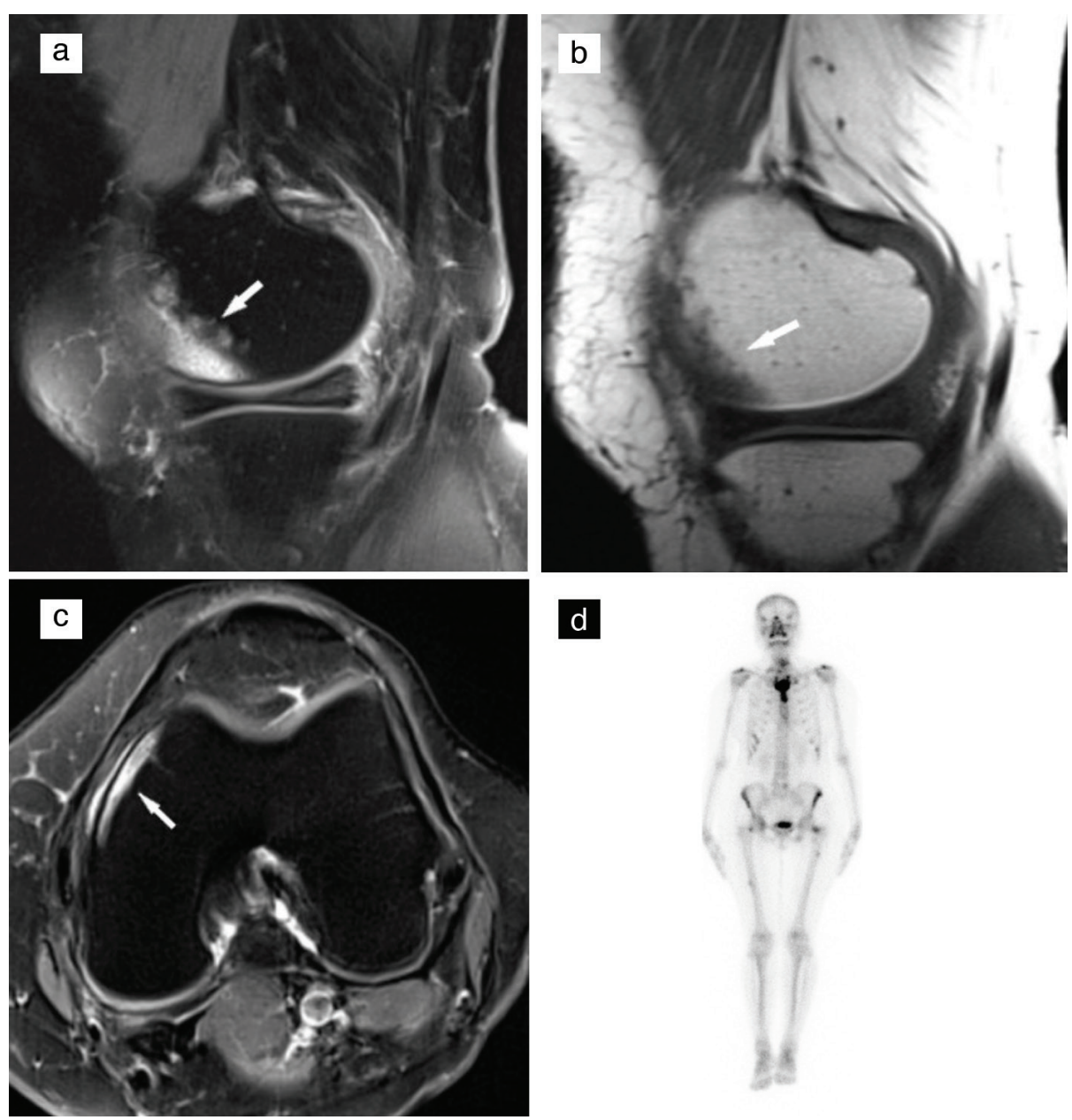

d

Figure 1. Magnetic resonance imaging (MRI) of a 55-year-old woman with breast cancer who has been on intravenous bisphosphonate for two years. $(a, c)$ Fat-saturated T2-weighted MRI showing increased signal intensity in the femoral medial condyle at the subcortical area (arrow); (b) T1-weighted image showing decreased marrow signal intensity in the femoral medial condyle at the subcortical area (arrow); (d) anterior views of the planar bone scan showing multiple areas of intensely increased activity in the skeleton, representing metastatic involvement. Despite this, there are no metastatic findings on scanning the knee. 

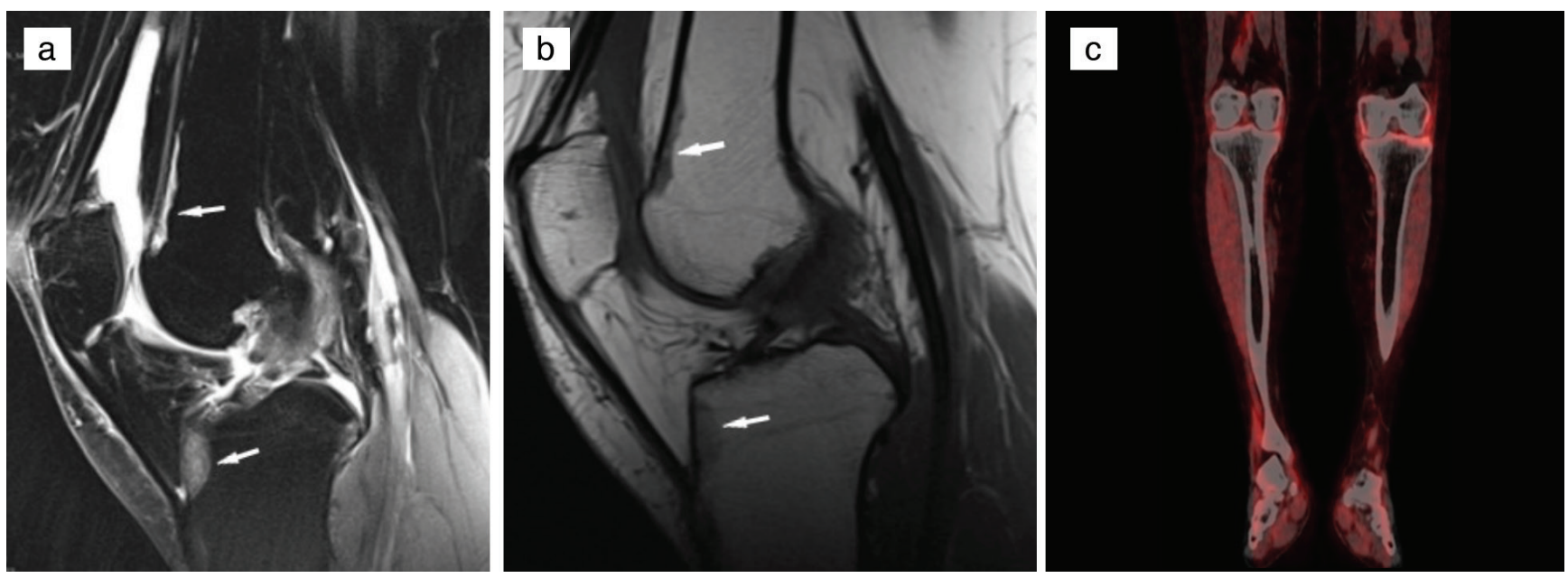

Figure 2. MRI of a 61-year- old woman with breast cancer who received intravenous bisphosphonate therapy for two years. (a) Fat-saturated T2weighted MRI showing increased signal intensity; (b) T1-weighted image showing decreased signal intensity in the femur and tibia at the subcortical areas (arrows); (c) there is no metastatic $\left.{ }^{18 f l o r-f l u o r o d e o x y g l u c o s e ~(18} \mathrm{F}-\mathrm{FDG}\right)$ uptake on coronal fused positron emission tomography/computerized tomography (PET/CT) image in the knee region.

Bisphosphonate treatment is increasingly used in patients with osteoporosis and metastatic carcinomas (1). Bisphosphonates inhibit osteoclast function and normal bone turnover. Bisphosphonate-related ischemic changes in the mandible and maxilla were reported in several studies in the literature (2). Bisphosphonate-related osteonecrosis of the jaws was first reported by Marx (3) in 2003. In our report, all lesions were located at the subcortical areas of long bones with low signal intensity on T1-weighted images and high signal intensity on T2-weighted images. Osteonecrosis and metastatic lesions show similar signal abnormalities on MRI. Because of this fact, nuclear medicine imaging or histopathologic examination is required to exclude metastatic lesions. Saito et al. (4) recently reported that histopathologically proven osteonecrosis appeared as abnormal multiple focal bone lesions in the femur and tibia, mimicking metastasis.

The duration of intravenous bisphosphonate treatment was more than one year in all patients, and there was no history of other drug use causing bone marrow signal change, such as erythropoietin or granulocyte stimulating factor, in these patients. In the follow-up of these patients, the bone scan and PET/CT supported the diagnosis of MRI by excluding metastatic involvement in these bones. Bone scan findings might vary according to the stage of osteonecrosis disease. In the acute phase of osteonecrosis, bone scintigraphy may not show technetium-99m methylene diphosphonate accumulation. After one to three weeks, increased radiotracer uptake is seen during the bone remodeling process (5). The uptake of ${ }^{18} \mathrm{~F}$-FDG is a marker for the tissue metabolism of glucose and represents the benign and malignant lesions as well as infections and sterile inflammation. In most cases reported in the literature, osteonecrosis revealed focal ${ }^{18} \mathrm{~F}-\mathrm{FDG}$ uptake. Talamo et al. (6) reported osteonecrosis in long bones, including the femoral and humeral heads, without ${ }^{18} \mathrm{~F}$-FDG uptake (7). In our patients, bone lesions defined on MRI did not show ${ }^{18} \mathrm{~F}$-FDG uptake and lytic/sclerotic density on PET/CT examination.

As a result, abnormal signal intensities detected on MRI can mimic metastatic bone lesions in patients with primary malignancy. In this report, we described osteonecrosis-like signal abnormalities of the long bones in patients that used long-term intravenous bisphosphonate treatment. The exclusion of metastatic involvement of these sites described on MRI was made using nuclear medicine examinations. Radiologists should keep in mind the probable diagnosis of osteonecrosis mimicking metastatic lesions in patients with primary malignancy. Bone scan and ${ }^{18} \mathrm{~F}-\mathrm{FDG}$ PET/CT are useful examinations in the evaluation of bone lesions detected on MRI, suspicious for metastatic disease. 


\section{Ethics}

Informed Consent: Consent was obtained from the two cases in the study.

Peer-review: Externally peer-reviewed.

\section{Authorship Contributions}

Surgical and Medical Practices: I.T., M.A., A.A., Concept: i.T., M.A., A.A., Design: I.T., M.A., A.A., Data Collection or Processing: I.T., M.A., A.A., Analysis or Interpretation: I.T., M.A., A.A., Literature Search: I.T., M.A., A.A., Writing: I.T., M.A., A.A.

Conflict of Interest: No conflict of interest was declared by the authors.

Financial Disclosure: The authors declared that this study received no financial support.

\section{References}

1. Obinata K, Shirai S, Ito H, Nakamura M, Carrozzo M, Macleod I, Carr A, Yamazaki Y, Tei K. Image findings of bisphosphonate related osteonecrosis of jaws comparing with osteoradionecrosis. Dentomaxillofac Radiol 2017:46:20160281.

2. Ruggiero SL, Mehrotra B, Rosenberg TJ, Engroff SL. Osteonecrosis of the jaws associated with the use of bisphosphonates: a review of 63 cases. J Oral Maxillofac Surg 2004;62:527-534.

3. Marx RE. Pamidronate (Aredia) and zoledronate (Zometa) induced avascular necrosis of the jaws: a growing epidemic. J Oral Maxillofac Surg 2003;61:1115-1117.

4. Saito $A$, Nakamura $Y$, Tanaka $R$, Inoue $S$, Okiyama $N$, Ishitsuka $Y$, Maruyama H, Watanabe R, Yoshida K, Ishiko A, Fujimoto M, Shinkuma S, Fujisawa Y. Unusual Bone Lesions with Osteonecrosis Mimicking Bone Metastasis of Squamous Cell Carcinoma in Recessive Dystrophic Epidermolysis Bullosa. Acta Derm Venereol 2019:99:1166-1169.

5. Agrawal K, Tripathy SK, Sen RK, Santhosh S, Bhattacharya A. Nuclear medicine imaging in osteonecrosis of hip: Old and current concepts. World J Orthop 2017:8:747-753.

6. Talamo G, Angtuaco E, Walker RC, Dong L, Miceli MH, Zangari M, Tricot G, Barlogie B, Anaissie E. Avascular necrosis of femoral and/or humeral heads in multiple myeloma: results of a prospective study of patients treated with dexamethasone-based regimens and high-dose chemotherapy. J Clin Oncol 2005;23:5217-5223.

7. Choi KH, Oh JK, Kim SH, Yoo ID, Choi EK, Han EJ. Osteonecrosis Mimicking Bone Metastasis in Femoral Head on (18)F-FDG PET/CT: A Case Report. Nucl Med Mol Imaging 2011;45:68-71. 